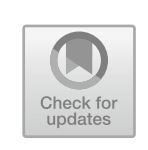

\title{
The Gambling Permeation? Cultural, Social and Economic Intersections Between Games and Gambling
}

\begin{abstract}
Games, digital or otherwise, have always taken inspiration from their broader social, cultural and economic surroundings. They have been used to attempt to teach moral values and changed to reflect new, more modern, ideals. Their recent development is contingent on changing technological infrastructure, giving rise to a multi-billion pound entertainment commodity. Developing concurrently, gambling commodities are also deeply tied to technology with ever changing modern gambling industries reflecting shifting normative values about the role and position of gambling in our lives. As gambling has become more acceptable, more "normal", its visibility has vastly increased. Against this backdrop it, perhaps, feels increasingly obvious that gambling would increasingly permeate digital games: game designers look to mechanics which hook people into products; games reflect broader societal trends and there is a pressing need to make returns on investments, commoditising play at a hitherto unknown scale.
\end{abstract}

Keywords Gambling · Gaming · Technology · Board games · Casual games $\cdot$ Normalisation

H. Wardle, Games Without Frontiers?, Leisure Studies in a Global Era, https://doi.org/10.1007/978-3-030-74910-1_2 


\section{What Games Say About Us}

It's 10.30am on Good Friday, 2018. My daughter and I are diligently queueing at the British Science Museum with what feels like hundreds of other parents and their kids. What are we waiting for? Entry to the now annual Power UP event, an event so popular tickets must be booked months in advance. Power UP describes itself as a hands-on gaming extravaganza, an immersive journey through the history of games. It is, but it is so much more. For me it's an opportunity to travel back in time and relive the wonder days of the Sega Mega Drive-to remember and reflect on those heady afternoons and evenings spent locked in the spare room with my brother getting Sonic to collect his gold rings (or Arnold Palmer to sink a hole in one!). The familial bonding the Mega Drive engendered was, for me, an important part of its appeal. It's also a time to reflect both personally and collectively on our shared experiences and the evolution of digital games. For me, that ranges from playing the standalone space invaders console that was passed down to me from my brother, to the simple BBC consoles I first used in primary school with their black screens and green script, to the designs of $1990 \mathrm{~s}$ biggest names (Goldeneye, anyone?) whose graphics now look positively primitive compared with digital games today. The Power UP event is an opportunity to re-engage with these games, from Pong to Halo. That it's now an annual event is testimony to the affection that digital games hold for many but also the growing place and importance that digital games have in cultural life. Mainstream recognition of the cultural importance of games was further affirmed when the British Victoria and Albert Museum, which for over 150 years has been the custodians and arbiters of British cultural life, launched a major exhibition on video games in 2018, describing them as a vital medium (Hunt, 2018). This was some six years after the Museum of Modern Art (MOMA) in New York added 14 digital games to its permanent collection.

The precise origins of digital games are contested but many give attribution to William Higinbotham, affectionately nicknamed the "grandfather of video games" (Stanton, 2015). In 1958 Higinbotham was the head of the instrumentation division at Brookhaven National Laboratory-a government-owned national laboratory specialising in nuclear physics. Each year Brookhaven hosted an annual open house, where the general public could visit the institute though it was often felt that the "Average Jo" failed to engage with (or understand the value of) the 
machines they encountered. What Higinbotham needed was an interactive way of demonstrating the work they were doing; an early example of what academics now call "public engagement". The result was "Tennis for Two" the first interactive game where two players knocked a ball back and forth across a net (Stanton, 2015). The game was an extension of the institute's work on plotting missile trajectories using their custombuilt analogue computer which had also, fortuitously, been programmed to calculate trajectories of bouncing balls. Based on this, the "Tennis for Two" game was born. At the open house in October of that year, it was a hit. People (teenagers mainly) queued to have a go, as one commentator noted "you couldn't pull them away from it!" (Stanton, 2015: 20). A particularly prescient comment given ongoing debates about the "addictiveness" of digital games.

These early digital games tended to take "real" life activities and games and attempt to replicate them within the digital environment. Tennis, ping pong and football were all early prototype digital games, as was Alan Turing's early attempts to programme a chess game (Stanton, 2015). In a time when game developers were computer scientists seeking to use games to explore and demonstrate the power of computers, the natural inspiration was the familiar. As a tool to exemplify the power and possibilities of these new machines, replicating the familiar was a sound strategy-the object was not necessarily the game play itself, but rather to showcase the possible. As digital games developed, and the objective became game play itself, the range of cultural references developers drew on expanded. Yet, there was still a tie to the familiar or the current. In the early 1960s the next wave of games often drew heavily on themes of space (Kerr, 2006). This is not surprising. The 1960s were the height of the "space race", with Russia and the USA competing for superiority, and some early game developers were embedded within military and space research programmes (Kerr, 2006). Themes of space were replicated in other cultural domains. It's no coincidence that the 1960s also saw the launch of seminal TV programmes like Star Trek or Lost in Space. Science Fiction was increasingly popular and many game designers, as Sci-Fi fans, reflected this in their games (Kerr, 2006; Williams \& Kahn, 2013). There is a clear theme of cultural producers, including early games designers, drawing inspiration from the preoccupations of current life. It was, as one of the co-developers of the 1961 game, Spacewar!, described, the "obvious thing to do" (Stanton, 2015: 33). 
Of course, borrowing from real-world games and transferring them to emerging digital environments remained popular, as can clearly be seen with games like Pong. Released as an arcade game in 1972, Pong became one of the first games to gain widespread recognition and popularity. Its simple premise, replicating features of tennis, and short game cycle made it the perfect game to be played in bars and arcades with and against friends. Pong was a social experience, though you could play against the machine-the fun was to play against other people. As the 1970s developed, the computer game industry expanded rapidly and game developers took inspiration from a number of sources. Some games, such as maze chasing game Gotcha, don't fare well when viewed from modern perspectives. Its aim was to chase a player around a maze and attempt to "kiss" them. The marketing was suggestive, with the box clearly showing a man chasing scantily clad women and the now-infamous controllers made to replicate breasts (though these were removed on release) (Stanton, 2015). Yet, when viewed in context of the period in which they were developed, this marketing and content has clear similarities with many popular, yet bawdy, films and television series of the era, which included Benny Hill's TV show, featuring Hill chasing scantily clad women, or soft porn films. Arguably, following the increasing popularity of films featuring more explicit sexual content, like Emmanuelle or Last Tango in Paris, some developers felt that people didn't want games to just shoot down spaceships and a whole series of controversial and semi-pornographic games emerged (Kaser, 2020). One of the most notorious was Custer's Revenge, which featured a naked General Custer having sex with a Native American Woman. Others included Beat 'em and eat 'em-in which the object of the game was to make naked women catch and eat male ejaculate. Controversy about sexual content within digital games continues to this day.

Though salacious and infamous, these games were certainly not mainstream. By the late 1970s and early 1980s game developers were also looking to films for inspiration and, in a sign of the rapid commercialisation of the industry, were signing licensing deals with film studios for the rights to produce games based on popular films. Film studios were also increasingly looking to digital games to expand their marketing and franchising of big-budget titles. Games were becoming part of global media landscapes (Albarrán-Torres, 2018). In the late 1970s Warner Communications bought Atari, the most successful games producer to date, and saw distinct opportunities in developing and mass-producing games of some 
of their largest cinematic releases. It was the art of the cross-sell, of crosspromotion. But it back-fired, badly. In 1982, Atari released their "Raiders of the Lost Ark" game, replicating the film plot whereby Indiana Jones searches for the Lost Ark of the Covenant. It was broadly well received. Other ties ups ensued, though the one of legend is Atari's E.T. game, based on Spielberg's film of the same name. Rushed through development in order to be released for the Christmas market, Atari reputedly manufactured more E.T. games than it had sold consoles on which to play it. The game sold badly and led to one of gaming's greatest urban myths: the Atari landfill dump in New Mexico in 1985, where it was reputed that millions of unsold E.T. cartridges were buried (an excavation in 2014 revealed it to be far fewer than the myth propounded, at just 700,000 games) (Stanton, 2015). But the cross over between films and games proceeded unbated. Game versions of Ghostbusters were produced in 1985, to support the film's release. Like the film, this was a success and testimony to the enduring brand of Ghostbusters. Numerous Ghostbusters games have been reimagined and launched over the years, including as recently as 2009 .

By the mid-1990s, the links between games and film were clear: one of the most successful was 1997s Goldeneye, based on the film of the same name that rebooted the James Bond franchise in 1995. However, the cultural impact and influence of games had grown, and no longer were games simply reflecting developments in other media-they were creating new icons of their own. Nintendo were the pioneers of this move, with their purposively designed child-friendly aesthetic and the creation of Super Mario (William \& Kahn, 2013). As well as being key characters in their own games, the Super Mario Bros spawned a Top Ten hit single and had an entire album devoted to them (released in 1992); a movie (released in 1993) and a TV show (Super Mario Bros Super Show! First aired in 1989). One of the most famous character crossovers must be Lara Croft from the Tomb Raider series. First released in 1996, movie executives quickly saw the appeal of a "female" Indiana Jones-style character. Rights for the movie production were secured by Paramount Pictures in 1998 and the first Lara Croft movie released in 2001. This was followed by a sequel in 2003 and a reboot in 2018. The success of the Tomb Raider games meant that Lara became and remains an iconic character. Yet, her development and characterisation were deeply situated within the social and cultural contexts of the nineties. Lara, as a strong female protagonist, is just one example of moves in the 1990s to place women at the centre of 
the action. The 1992 film Buffy the Vampire Slayer attempted the same (followed by the TV series of the same name) and "girl power" was the idiom of the day. Lara, arguably, also was routed in and an exemplar of the "cool Britannia" wave that typified much of the mid-1990s. Finally, much was made of Lara's physical proportions, with tiny waist and enlarged bust, yet this too reflected 1990's icons such as Pamela Anderson and the hyper-sexualisation of women that was rife in the "lads mags" era. Lara herself appeared on the front page of "Loaded" magazine in January 2000 (pouting seductively at the reader, scantily clad with a pillow to cover her modesty). In short, the character and image of Lara Croft reflected the era in which she was conceived, and she became an enduring protagonist of those qualities.

These examples demonstrate a point powerfully made by Aphra Kerr, that new technologies, including games, "shape and are shaped by social processes" (Kerr, 2006: 12). This is important, especially as we consider how games and gambling may be becoming increasingly intertwined. Whilst Kerr was talking about digital games and their relationship with technology, her comments can, arguably, be extended and applied to all games, digital or not. We can trace changing social processes and cultural norms through their embodiment in the rules, objectives and regulations of games, where their content and rules reflect and refract the processes and preoccupations of everyday life. From the childhood game of "ring a ring a roses" drawing on experiences of plague, to chess, with a historical lineage stretching back over 1500 years reflecting hierarchal structures and notions of princely war, games have nearly always drawn inspiration from contemporary social, political and economic contexts (Donovan, 2018). Chess is an excellent example of this. Its origins stretch back to the Indian Gupta dynasty of c.300 A.D. The pieces and play reflected that society, with the Raj being the central point surrounded by advisors, war elephants and ships. As Tristan Donovan (2018) has traced, these precursors of chess were exported to other countries, often along trade routes, and each time changed to reflect the society in which it was now embedded: in Persia, the Shar replaced the Raj, ships replaced war chariots; in Britain, the King was the focus and war chariots replaced by Bishops. By the mid-1500s, the chessboard of Europe reflected other political processes: the rise of powerful female rulers, with the Queen emerging as most powerful position on the board. As Donavan (2018) has powerfully argued, the game of chess embodies centuries of world history. 
Arguably, these processes accelerated as games became commoditised. Companies and entrepreneurs sprung up specialising in game design, especially from the mid-nineteenth century onwards, and it was common to see games developed based on real-life events. On the 2 May 1912, just 17 days after the Titanic sank, William Edward Peacock of Peacock \& Co, a renowned and prolific producer of wooden jigsaws (Grace's Guide, 2016), copyrighted its new game called The New Game across the Atlantic complete with the tagline "from Liverpool to New York without touching icebergs!". It's unclear if this game was ever produced and distributed, but images of it can be found in the UK's National Archive. Others found that drawing on catastrophic events should be approached with care. In 1977 the board game, The Sinking of the Titanic, produced by the veritable games manufacturer behind titles like Twister or Hungry Hippos, was quickly recalled from sale after outrage because of its insensitive content. It was renamed and relaunched under the title Abandon Ship.

New games emerged which also reflected and exploited contemporary social structures. Anthony Pratt, inventor of the board game Cluedo, openly took his inspiration from great country house gatherings where he played as a musician, reportedly taking notes on the characters he observed there. He was also influenced by one of the most popular genres of the day: country house murder mysteries and crime fiction. Cluedo, with its mansion house setting and cast of now familiar characters, more than resembles the setting of many of Agatha Christie's most famous novels. This is no coincidence: this was the intention (Popovici, 2018).

Following the example of chess, the power of games to reflect cultural norms extends further than simply drawing inspiration from events and seeking to transpose them into games. Some games also drew on dominant political, social and economic idioms, recreating their practices and enforcing their primacy. In a notable scene from Buffy the Vampire Slayer, Anya, a newly human character (don't ask!) is babysitting Buffy's sister (Dawn) with her boyfriend (Xander). They are playing Game of Life. Anya, annoyed, moans "Crap. Look at this. Now I'm burdened with a husband, several pink children and more cash than I can reasonably manage", Xander and Dawn look confused: "that means you're winning!", "Really?" she says, looking pleased (Fury, 2000). The modern version of The Game of Life has its origins in a mid-nineteenth-century parlour game, where the players travel through life from infancy to old age with the objective to live a "good" life. As such, it was imbued with 
moral messages about what it meant to have a "good life". A good life was an "appropriate life" which included education, marriage, children but it also set out the ills that people should avoid: "gambling to ruin" was one such ill (Donovan, 2018). Milton Bradley, the game's inventor, dislike of gambling was so strong that the game did not and continues not to use dice because of their connotations and connections with gambling, using a spinner instead.

Milton Bradley was not alone, many early examples of Victorian and Georgian board games were imbued with moral messages, designed to educate the player about virtues to be valued. The New Game of Human Life (1798) was explicit, outlining the important moral instructions they expected parents to make whilst playing this game:

parents who take upon themselves the pleasing task of instructing their children or others to whom that important task may be delegated will cause them to stop at each character and require their attention to a few moral and indicious observations, explanatory of each character as they proceed and contrast the happiness of a virtuous and well spent life with the fatal consequences arising from vicious and immoral pursuits. (Liman, 2017)

The characters children would encounter were "The Temperate Man", "The Glutton", "The Learned Man" or "The Gambler". Instructive, certainly but whether the game was any fun is lost to the ages. Games like the Mirror of Truth (1848), subtitled as "a new game for the instruction of youth of both sexes" (Liman, 2017) built on these themes and expounded similar virtues. Players were rewarded by advancing if one landed on a virtuous trait but were punished for landing on a vice, such as idleness, impiety or passion. The more famous Mansion of Happiness (1800) operated in much the same way, drawing inspiration from earlier games like the Royal Game of Goose, where the objective was ostensibly to advance through life avoiding certain pitfalls such as prison or death. The Royal Game of Goose, as a classic race game, has origins stretching back to the fifteenth century. Seville (2016) has traced these origins and argued that the game was a "symbolic representation of spiritual progress of the human soul, a representation in which the geese denote favourable spiritual guidance while the hazards represent earthly temptations and pitfalls along the way". 
This tendency for games as instruction accelerated in the nineteenth century. And this instruction wasn't just confined to moral character but also focused on building godly relationships. One of my personal favourites, Wedding Bells (1911), shows players advancing towards matrimony if they took a stroll or went to a concert with their suitor, but heading back to square one for any discord with parents. The inventor of The Game of Life (or The Checkered Game of Life as earlier versions were known) was part of a unique breed of nineteenth-century entrepreneurthose who were deeply religious, moralists and educators - in Britain notable examples like Seebohm and Joseph Rowntree also belonged to this group (Edwards, 2020). However, as the twentieth century wore on, the nature of the instruction offered by such games changed to reflect more modern preoccupations. In the modern version of The Game of Life, published in 1960, the acquisition of points needed to achieve a "good life" was replaced with the acquisition of money. This changed the objectives of the game to be less about decency, honesty or virtue and more about personal gain, wealth and prestige-arguably reflecting broader changes in society at large and the rise of neo-liberal materialism (Donovan, 2018). Of course, these changes probably reflect awareness from the game designer that society had moved on, that intemperance and gambling were no longer considered "social evils" as Seebohm Rowntree and his colleagues once propounded (Rowntree, 1905). It is also doubtful that the general populace ever concurred with that assessment. But in changing these rules, they created a new incarnation of The Game of Life which reflected the dominant values of the day and replicated, and arguably reinforced, these values in the millions of households where this game was played.

This was not the only game that went through this transformation. The incarnation of Monopoly that we know today, where the objective is the accumulation of wealth through property acquisition, was developed in the mid-1930s and has changed little today (though arguably reflecting modern preoccupation with immediacy, a speed die has been introduced in some of the latest versions to help chivvy the game along). However, this is a far cry from the original intent of the game's developer. As traced by Tristan Donovan (2018), Monopoly's origins were intended as an anti-landlord tirade. It's precursor, the Landlord's Game, developed by Elizabeth Magie in 1904 was intended to demonstrate the innate inequalities of the current economic system-that the landlord gets their money and keeps it-ensuring that the rich get richer and 
the poor get poorer. According to Donovan, Magie was convinced that players would see the game's strong moral message and heed its warning. Except that buying properties, making money and ruining others turned out to be too much fun: as Donovan cites "If winning the game meant bleeding your opponent's dry: so be it. If Monopoly seemed like a celebration of dog-eat-dog capitalism, that's because that's what people really wanted it to be" (Donovan, 2018: 95). In the context of rising concern about communism, in the aftermath of the Great Depression and in the shadow of monopolistic giants of industry, it is difficult to imagine Monopoly developing in any other way. That said, Magie may have been pleased to learn that her vision wasn't entirely abandoned. The exposition of economic life and capitalist endeavour propounded by Monopoly came under scrutiny with the publication of The Anti-Monopoly game. First published in 1973, and still in-print today, Anti-Monopoly was created by Ralph Anspach, a University Professor, to warn about the potential harmfulness of monopolies. This may be different from Magie's original vision, but the game being used as commentary on our economic system is something that she would have recognised.

As Anya found out, according to games like The Game of Life or Monopoly, success now means the accumulation of wealth and such objectives arguably reflect the preoccupations of western capitalism in the twentieth century. This was a notable shift from these game's predecessors. As Jennifer Jensen (2009) has aptly traced, between 1850 and 1900, the ethos and objectives of games changed to reflect new societal preoccupations, which themselves were tied to weakening of the Protestant world view that success was obtained by virtue. Money not virtue is king.

\section{Games, Technology and Money}

So far, we have traced inspirations for the content of games, their aims and objectives and their thematic influences. In this respect, they can be viewed as cultural artefacts, providing insight into societal norms and idioms at the point of their creation. But clearly, this is not all. The modern digital games industry is also deeply tied to developing technologies, with technological infrastructures and platforms being used to connect and create ever more complex games and gaming ecosystems. These processes have been well documented and so are only briefly recounted here (see William and Kahn for an excellent account). As William and Kahn (2013) say, the modern digital games industry is deeply 
tied to network cultures underpinned and facilitated by the development and spread of the internet. It is tied to first, second, third, fourth and now fifth generation wireless technologies and to the drive for social connectivity. We see this in the development of Massively Multi Player Online Role-Playing Games, like World of Warcraft, where increased rollout of broadband wifi facilitated players around the world to connect and play with and against each other in a fantasy digital world. No longer do you and your pals have to meet in person to play, you can meet them, or someone else, online. And with this increased computing power came enhanced memory. Games developed where the universe in which you are embedded exists and continues even when you are not there, that remembers your characters, your skills, your features in perpetuity. Whilst processing power increased, the complexity and visual design of the gaming worlds depicted became more sophisticated-little wonder that some titles like The Sims or Minecraft now features in MOMA's permanent exhibition.

A further development is what has been termed the "casual games explosion" (Juul, 2010; Williams \& Kahn, 2013). With their origins within Social Networking Sites, mainly Facebook, these "casual games" which are usually free to play have, within a very short space of time, become one of the most successful elements of the digital gaming industry. The success of titles like FarmVille made producers of these "casual" games hugely successful. Zynga, the firm behind FarmVille, now have annual revenues of over $\$ 1$ billion dollars (Zynga, 2020). To put this in context, this single gaming company, which generates most of its revenues from three titles (including Zynga Poker), has annual revenues equaling a third of revenue reported by GVC holdings; GVC holdings being the parent group for over 30 different gambling brands worldwide, including Ladbrokes Coral and Party Poker (GVC, 2020). Not bad for a company founded in 2007. Other companies, like King.com, the group behind Candy Crush Saga, have had similar success, posting revenues of approximately $\$ 2$ billion in 2019 (Statista, 2020). These games are termed casual because, unlike console games, they don't require the same level of dedication to play, they are easy to learn and quite simply are cheaper, far cheaper, to produce-something evident in their visual style (Williams \& Kahn, 2013). And already, the industry has developed further with hyper-causal games the latest trend. Hyper-casual games are quick and simple, offering instant game play and are exemplified by games like my own favourite, Stick Hero, originally made by Ketchapp (a pioneer 
in the hyper-casual market) or the much more popular Helix Jump, which reportedly had over 25 million daily users by the end of 2018 (Venturebeat, 2019).

But the term "casual" belies a deeper range of processes that these games use to generate income-which relies on a whole range of mechanisms to obtain money. This ranges from using pay to win mechanics (that is getting people to pay to advance to the next level or to buy more lives) to buying in-games items and includes the kind of mechanics that games use to get people hooked and to keep them coming back (vital for advertising revenue, among other things). In Zynga's annual statements, they state that the purchase of in-game items accounts for most of their revenue-with this revenue largely being generated from around 3\% of players (Zynga, 2020). Attending an event at King.com headquarters in London, there was considerable focus on how to create "sticky" games-that is games that pull people back, time after time. King.com are legendary at this, with their Candy Crush Saga game being the ultimate exemplar. This has a seemingly never-ending series of levels to achieve, variable ratio schedule (meaning you never know if or when a win is around the corner, much like a slot machine) and the game itself imposes time-outs, creating desire to get back into it as quickly as possible (which can, of course, be circumvented by paying money). Variable rewards are deemed one of the most important tools that companies can use to "hook" users into their products and the pursuit of which can, according to Nir Eyal, be intoxicating (Eyal, 2014). Through these mechanisms, Candy Crush has proven to be highly "sticky". King themselves exclaim on their website that their games are "easy to pick up, but hard to put down". Sticky indeed. Millions and millions of players around the world agree-Candy Crush Saga is arguably one of the most successful "casual" games on the market.

Of course, the need to make money, to make profit, means evolving systems of monetisation have been developed which include the rising popularity of within-game micro-transactions. In free to play models, these micro-transactions, such as paying to level up or to obtain cosmetic items, are, along with advertising or releasing new downloadable content, critical to generating income. For console games, they are a powerful way for corporations to further profits, with the costs of game development rising exponentially but the costs of the games themselves staying relatively static. It is these processes which Johnson and Brock (2019) have argued have led to the "gambling turn" within digital games, as 
corporations look for ever more innovative ways to obtain money from players. This turn includes but (is not limited to) the development of loot boxes (discussed fully in the next chapter). This is a powerful and important explanation. But equally, we can see how games have always borrowed from contemporary cultural capital, how they are embedded within and represent the zeitgeist of the moments in time when they were created (Albarrán-Torres, 2018). When we also trace the commodification of the gaming industry, we can see similar relationships with technological development and the "gambling turn" should also be viewed as inextricably linked to and embedded within broader narratives about the role of gambling in everyday life.

\section{Observing Change Through Perspectives on Gambling}

If gaming is a lens through which we mark changing social processes, then so too is gambling. I distinctly remember the first time this was put to me-sitting on the banks of Lake Tahoe, having escaped the Harrah's casino which was hosting the latest international conference on gambling, with my colleagues Gerda Reith and Fiona Dobbie. Conversation turned to how we'd got into gambling research, and Gerda said she loved looking at gambling because "it was a lens through which you could examine nearly any social process". She is, of course, right. When we look at the history of gambling, the way its treated and regulated is embedded within prevailing political, social and economic contexts. Reith herself has traced these patterns in her peerless book, the Age of Chance (Reith, 2000).

Today, we all too often consider gambling to be an innate part of life; that where there is competition, there must be wagering. We see this with the development of games, where early origins of chess were initially considered controversial because of their associations with dice but also with wagering. This became particularly pertinent with the rise of Islam, where the associations between betting and chess led to a long and controversial debate about the role of chess in Persian society (Donovan, 2018). Notable examples of dice being discovered among the ruins of ancient communities, of the Greeks rolling bones, do little to dispel the idea that gambling is and remains an innate part of life. So, do we have an innate instinct to compete against others, to accelerate this competition by laying of stakes? Anthropologists say not. They have found little evidence of gambling among certain indigenous communities, arguing 
that "there is no specific gambling instinct" (Binde, 2005). Our understanding of what gambling means is shaped by the context and social practices that surround it. Our current framing of gambling is one of risk and reward, where wealth is accumulated by the victor. Yet Per Binde (2005) has documented the ways in which gambling has been used in other communities. Instead of being an extractive process, he notes how in some communities, such as the Hadza of Tanzania or the Canadian Inuit, gambling was a way to redistribute scarce resources; the means to ensure that one person or unit within the community did not obtain too much of a commodity necessary for survival. This practice of gambling is a far cry from our current notions, where meanings attached to gambling are viewed through (western) capitalist idioms.

Yet perhaps the simplest evidence is that if gambling is innate then shouldn't we all be doing it? A country like Great Britain is ideal to explore the notion of the gambling instinct. Britain has arguably one of the most liberal gambling regimes in the worlds: you can gamble whilst collecting your groceries, you can visit casinos or bookmakers on your high street, you can play slot machines whilst waiting for your trainyou can gamble any time, day or night, on an army of different online products. Because of legislative change, you are actively encouraged to do this through heavy advertising and promotion. Yet still, many of us don't gamble. According to the most recent data, collected in $2016,46 \%$ of British adults hadn't gambled in the previous 12 months (Connolly et al., 2018). And despite its seeming ubiquity, only $9 \%$ of adults gambled online. There are good reasons that online gambling companies still see Britain as a promising proposition - if the vast, vast majority of adults don't engage in online gambling, then there is a large target market still to shoot at.

What these examples tell us is that gambling is socially constructed and determined and, like games, tracing its history sheds light on a whole range of changing social processes. Looking at the near past, in Britain specifically, we can see these processes in action and review of them gives insight into what might happen next, or at least suggests what future trends we should pay attention to. When viewed in this context, this arguably makes the so-called gambling turn within games a lot less surprising.

In the mid-nineteenth century, gambling in Britain was about to witness a period of unparalleled acceleration: a result of dual processes of technological change and of urbanisation. The technological changes 
assisting this acceleration were twofold-first the development of the telegraph system which enabled the swift communication of results from racecourses - far quicker that carrier pigeon-resulting in a buoyant and dedicated racing industry press. The second: the rise and expansion of the railways, connecting people to racecourses in an unprecedented way and opening racing to the populace for the first time (Chinn, 2004; Reith, 2000). Now, for the price of a railway ticket and the cost of entry, horse racing was no longer the preserve of the elite. These developments created the conditions for gambling, and specifically wagering, to develop on a larger, more organised and commercial scale. Though technically prohibited, bookmaking flourished and, according to the historian Mark Clapson (1992), industrialisation and rapidly growing cities provided densely populated communities in which betting proliferated (the darker side of which is currently exemplified in the BBC's drama, Peaky Blinders).

During this period, attitudes to gambling and its associated enactment in law, were shaped by assumptions of class, paternalism, social inequity and poverty (Reith, 2000). Gambling in Britain has a long lineage though early attempts to legislate tended to have the dual focus of protecting the elite and wealthy from ruining themselves and preventing those of lower classes from participating, in order to "protect them" from themselves. The 1845 Gaming Act, for example, legislated that gambling debts were unenforceable as a legal contract. This piece of legislation single-handedly stopped the flight of English aristocrats to the continent to avoid paying gambling debts. Getting aristocrats to pay their debts was increasingly problematic and 1844 a lawyer prosecuting Lord George Bentinck for debts owed thundered "why are immoral practices to be condemned in one class and allowed in another... Why should a man in a higher station of life be allowed to do anything, when those of a lower rank are thus to be punished for doing the very same thing. Can that difference be reasonable? Can that difference be honest, can it be just?" (Foulkes, 2010: 255). The case was lost but the point was made, though this wasn't to be addressed in legislation for another 115 years.

This inequity was enshrined, repeatedly, in law. The rise of gambling among the working classes was viewed with consternation among many, particularly the ruling elite. There were concerns about productivity, concerns about ruin, concerns about criminality but also concerns that gambling, among other things, violated the fundamental ethos of living a 
virtuous life earned through hard work and self-improvement: the protestant work ethic. Gambling violated the self-same values and morals that many games of the time attempted to instil in their players, as evident in the punishments meted out to those who encountered "The Gambler" during play. When viewed in these terms, as a contravention of God's Will, the solution was not to level the playing field between the working and ruling classes, but rather to view gambling as a vice that should be stopped for all. In 1890, the National Anti-Gambling League was established, funded by well-known social reformers like Seebohm Rowntree. Gambling became a crucial issue in debates about the conditions of the working classes and a key aspect of social reform movements (Clapson, 1992). Seebohm Rowntree was at the forefront of rallying against gambling arguing that it was a "social evil" that kept the working classes subjugated and which propagated poverty and inequality (Rowntree, 1905). Yet despite these social reform movements, and their success in influencing legislation, their views were not necessarily shared by the populace at large.

During this time, facilitated by quicker communication of results and easier access to racecourses, horse racing and horse race betting grew in popularity. In Britain, the Derby was not just a horse race but a full-scale gambling event, with mobile gambling booths, complete with thimble riggers, hazard and early versions of roulette, transforming the areas around the racecourse into temporary gambling dens. The Derby, and its American counterpart, the Kentucky Derby were such culturally important events that they too became the inspiration for board games. In the USA, the Macloughin Brothers copyrighted the Derby Steeple Chase Board Game in 1888 and most games manufacturers produced horse racing games at this time. There are examples of horse racing games extending back to the 1840s and they took on many formssome were race track games where you moved your "horse" around the track according to what you threw with your dice; others were simplerlike the German manufactured pocket watch game (1905), where you simply twirled the central spinner and whichever horse the pointer landed on won the race. The UK's National Image Archive contains copies of "The Derby Winner's Game" published in 1898 and in 1911 of "The Grand National Game". One of the more unique games developed was the partnership between Bing Crosby and H. Fishlove \& Co. Fishlove, most famous for their daft and risqué gag boxes, teamed up with Crosby, a lifelong horse race lover and owner (he was part owner of Meadow 
Court, an Irish Derby winner) to launch the "Bing Crosby Derby Horse Race Game" in 1947. This brought together famous horses, like Seabiscuit or Alsab to race around the board whilst the player bet on the outcome, using the in-game currency or real money. The game itself started with setting the odds. The function of this game was to bet and was advertised as an "All American game for adults and children". It was immensely popular, no doubt in part due to the tremendous star power of Crosby himself-shop fronts were adorned with pictures of him and his pals playing the game and it was so successful that in 1948 a "popular" version costing just \$1.98 was launched-Crosby's Horse Race Derby Game became truly accessible to the masses.

If these examples show anything, it is the enduring appeal and popularity of horse races and horse race betting during this time. In Britain, in 1951 a national survey of gambling estimated that $44 \%$ of the British population bet on horses, with between 10 and $13 \%$ betting once a week or more. In addition, $4 \%$ bet on dog races and $39 \%$ bet on football pools. The results were so striking that the authors of the study concluded that "Betting in Britain is almost a universal habit" (Kemsley \& Ginsburg, 1951). These results are striking because in Britain in the 1950s, with the exception of the football pools, very few forms of gambling were (legally) open to ordinary people: there were no lotteries, no scratchcards, no legal casinos or bingo halls (though plenty of bingo), and bookmakers were only legally available on-course or off course for credit betting (a means not generally available to ordinary people). Yet, there was plenty of nonlegal provision and as these figures show, despite the moral and social repudiation shown towards gambling by the ruling elites, gambling and betting remained a notable pastime for some.

Befitting the idea of gambling as a microcosm through which to observe social processes, in Britain, major legislative change was enacted in 1960 and again in 2005. Both times, the nature of the changes were situated in broader political and philosophical idioms. By 1960, the Labour Party had become increasingly uneasy at the inequity enshrined within gambling legislation: 115 years after lawyers had raged about having one rule for the ruling classes and another for the working man, the Labour Party finally agreed. Removing class-based inequity from betting legislation was a Labour Party Manifesto Commitment in 1959 and in 1960, the Labour Party helped the then Conservative government to vote through change, mainly by abstaining-the legislation passed by 331 votes for to just 49 votes against (Laybourn, 2008). 
The 1960 Betting Act was transformative in that it paved the way for legalised bookmakers' offices to be opened. But did so in a limited way-the Government was at pains to ensure that bookmakers would not be attractive places, especially not to women or children (no seats, no comforts- the aim was to get in and get out). There was a palpable sense of the Government saying "fine, you can bet, but we're not making it pleasant for you".

These historical trends, with technology facilitating wider and faster communication and the legal status of gambling changing to reflect broader social concerns, amplified as the twentieth century wore on. Just as the gaming industry spent the 1980s and 1990s innovating, developing and commercialising their products, so too did the gambling industry. Indeed, it was technological development and changes in communication infrastructure that helped to reignite calls for a British National Lottery (along with changing political leadership, Margaret Thatcher purportedly disapproved of gambling on moral and religious grounds). As Ken Hargreaves, MP, in 1991 noted, "The advent of computer technology and enormously improved communications begin to make safe honest lotteries once more a practical proposition in the 1990" (Hansard, 1991). No longer could concerns about integrity or trust be used to argue against a national lottery-advances in technology saw to that.

Whilst gambling started to be legalised, commoditised and accepted into everyday lives, there were those who also raised prescient concerns. As early as 1978, Lord Spens, in a speech to the House of Lords, remarked:

With the advent of the computer chip, who knows what new methods of gambling will not be introduced, to interest and attract people who now do not gamble very much in the traditional ways? I am here thinking particularly of women, most of whom gamble only on bingo, but few of whom, apart from bingo, are regular gamblers. They seem to offer a very large target for enterprising gambling operators to shoot at with some new-fangled computer chip gambling idea. (Hansard, 1978)

One can only imagine his thoughts had he lived to see the development of online gambling, with bingo and casino sites aimed specifically at women. Yet, Lord Spens was not a puritanical campaigner, he was what we'd now call an "expert by experience". He knew first-hand the harms excessive gambling could cause. In 1974 he was jailed for stealing $£ 151,000$ 
from the Federation of British Carpeting Manufacturers, of which he was the Director, to fund his gambling and during his trial the court was told he had attempted suicide. It was this experience that compelled him to action, calling for an overhaul of the system to protect people from gambling harms.

Others raised concerns about where technological developments may take us, specifically in relation to furthering the accessibility and visibility of gambling. In an 1980 House of Commons debate, Mr Gary Waller MP speculated:

we can foresee the time when football pools will be done on an automatic basis. People will sit at home and call up the coupon on their television screens, then mark their crosses on the screen. Their bank accounts will be debited automatically.....that sort of situation is probably closer than many people think. (Hansard, 1980)

If we replace television with smartphone or laptop and football pools with sports betting, then Mr Waller speaking back in 1980 had no idea quite how right he'd turn out to be. Quite quickly, the predictions of Lord Spens and Gary Waller were taking shape. By 1985, the British Parliament were debating The Bingo Bill, which among other things, would allow multiple bingo clubs to link together via a computer to offer much larger shared bingo prizes. This shared prize pool would offer winnings of up to $£ 50,000$, altering the nature of the product on offer from small stakes, small prizes to larger prizes, underpinned and facilitated by changes in technology.

By the early 1990s bookmakers were advertising live odds on sports through dedicated Teletext pages and providing phone numbers so that punters could ring up and place their bets. Teletext, first broadcast on 1 January 1993, was accessed by pressing a button on your TV remote control, bringing up an index of content which viewers then chose from by typing in the page number of what they wanted to access. This opportunity was not lost on bookmakers, who used Teletext to advertise their odds and supplied phone numbers for bets to be placed. This might have all gone under the radar were it not for a high-profile court case, brought by the prominent British bookmaker Victor Chandler in 1999. Victor Chandler International had moved its operations to Gibraltar ostensibly to escape British gaming duty but wanted to join British compatriots in advertising their odds through Teletext, supplemented with a freephone 
number for punters to call to place their bets (providing they were over a set amount). But they were told by Custom and Excise Officials that this would not be possible. A High Court trial ensued, and the courts backed Victor Chandler. Unlike Britain, there were no gaming duties to be paid on winnings collected from a company based in Gibraltar and politicians were aghast that offshore betting would circumvent the collection of this tax. Following the High Court ruling in July 1999, the Government announced it would ban offshore companies from advertising on Teletext. It was the money, and loss thereof, that exorcised politicians. The accessibility of betting from your own home was not called into question; that was fine so long as it didn't impact on homespun businesses and, of course, the tax take of government.

The Teletext and phone betting model was the precursor to internet betting. It was of little surprise, therefore, that certain forethinking bookmakers saw the early opportunities of the internet and opened online betting websites: Stan James, a notable operator with an especially large Teletext presence, was one of the first to do so, opening their website in 1997. By 2001, the Chairman of William Hill was lauding the Chancellor's decision to replace gaming duty levied on winnings with a tax on profits, stating that this provided "a real opportunity to be world leaders in online betting" (Daily Mail, 2001). By 2002, Gary Waller's prediction had come true-Sky Bet became the first to launch their Teletext betting service, where pressing the Red Button on your remote control would allow people to find and place bets through their television. In just a few short years, internet and interactive gambling had arrived, and it was now lauded as the future of the industry.

And it wasn't just bookmakers capitalising on new technology, online casinos were at the forefront of this movement too. From around 1994, new companies were formed, like Microgaming and Intercasino, focusing solely on the provision of online casino platforms. Debate abounds regarding who was the first to offer online casino games, but Microgaming's The Gaming Club and Cryptologic can certainly claim to be among the first. By 1996, Cryptologic's InterCasino was offering internet casino games with a fully integrated online payment system (just as Gary Waller envisaged). The development of these integrated payment mechanisms was critical in allowing online gambling to thrive.

Following shortly after online casinos and online bookmaking was online poker. Online poker and its boom through the early twenty-first century became the poster child for online gambling. Suddenly poker 
became mainstream with industry-leading companies, like Poker Stars, or Party Poker rapidly becoming billion dollar entities. The "Poker Boom" as it has been called occurred mainly between 2003 and 2006 and transformed poker, in America at least, from what had been a relatively niche to mainstream event. Online poker companies made savvy business links with the World Poker Tour (WPT) and the World Series of Poker (WSOP) who both launched much improved televised broadcasts at the same time. Party Poker started to sponsor the World Poker Tour. Online poker really attracted attention when in 2003 Chris Moneymaker, a Tennessee accountant, who'd won his seat at the WSOP through a \$39 Poker Stars tournament, won the World Series taking home $\$ 2.5$ million in prize money (Holden, 2008). The subsequent growth of online poker was dubbed the "Moneymaker effect". Televised poker grew in popularity, with people following the WPT. By 2004, it was broadcast in over 60 countries and it is estimated that around 2 million people in the USA alone tuned into each episode (Boxing Scene). As with gaming, online poker transcended its North American origins and became part of the transnational, global media landscape (Albarrán-Torres, 2018).

In the USA, and around the world, poker boomed. Online poker grew but in countries like Britain so did poker clubs, with new clubs opening and tournaments being hosted out of pubs. In 2010, it was estimated that around one million British adults were playing poker in pubs or clubs (Wardle et al., 2011). Celebrities played and celebrities endorsed poker, it quite simply made its way into the mainstream. It is of little surprise, then, that the first game ever launched by Zynga in 2007 was Texas Hold 'em Poker, albeit played for virtual chips rather than real money. Zynga were simply joining the poker boom bandwagon and continued to ride this wave, hosting poker tournaments, partnering with the WPT and making a short-lived foray into "real money" poker in Britain.

Whilst the poker boom, in the USA at least, didn't last (legislation saw to that) its existence during that time was prolific and was, arguably, part of a wider trend towards gambling gaining greater visibility, greater acceptance and greater normalcy within society. In Britain, gambling was about to undergo a renaissance, with the Labour government of Tony Blair keen to reposition gambling as a normal leisure experience and regulate it at such. In the USA, views remained disparate on a state by state basis and the Unlawful Internet Gambling Enforcement Act saw to it that online gambling would not proliferate. Yet similar rhetoric put forward by the British Labour Government around gambling as leisure abounds 
within the USA and gradually individual states are starting to open up to gambling opportunities-especially online sports betting and online casinos.

Recently, there has been much talk about the normalisation of gambling, with much focus being placed on the role of sports, sports sponsorship and advertising in facilitating this, alongside the greater accessibility offered by online products. In Britain, "normalisation" was a government policy (not that it would be openly called such). The legislative change ushered in by the 2005 Gambling Act specifically wanted gambling to come out of the shadows and take its place as a legitimate leisure concern. As Tessa Jowell, the minister responsible for steering the legislation through parliament, stated: "In the future, well-informed adults will have greater freedom and choice to spend their leisure money on gambling if they want to. The law will, for the first time, treat them like grown-ups" (Light, 2007). This British government-sponsored normalisation has a long lineage, arguably beginning with the introduction of The National Lottery in 1994. But we should also not forget gambling legislations' historical antecedents, where despite repeated attempts at government control, many people quite simply continued to bet or to gamble. By the mid-2000s government policy focused increasingly on the individual, encouraging individuals to take responsibility for their vices and to make the "right" choices: with regard to health, people were encouraged to "choose health" (though Smokefree legislation showed that government wasn't beyond imposing choices when needed). Gambling was no different. Gambling would be allowed; gambling would be promoted, and it was up to the individual to shoulder the responsibility of their actions. The result: gambling became an increasingly present feature of everyday life, with adverts, sponsorships and promotions evident in abundance and gambling and betting brands becoming as well known as John Lewis, Tesco or Walmarts.

\section{The Gambling Permeation?}

There has been a great deal of consternation from academics, policymakers and regulators alike about the increasing incursion of gambling and gambling-like features into games. Part of this has an economic explanation, where gaming companies need to create ever more inventive ways to generate profits from their games, and create games that keep people coming back to them. In this context, the psychological features that 
make gambling compelling, of risk and reward, of uncertainty and excitement, also make games compelling. But this is not all. As this chapter has traced, games and gambling do not exist as entirely separate entities. They are entwined: from the moralistic games of the nineteenth century, attempting to show the vice of gambling, to games developed concurrently reflecting the popularity of horse races and betting, to the poker boom of the early twentieth century, which helped to generate an entirely new genre of game: the social casino. Games and game designers have long taken inspiration from broader trends in the social world in which they exist. At a time when discourses around gambling changed from vice to leisure, when gambling's visibility has markedly increased, supported by global media giants, sporting power-houses as well as the internet, it perhaps seems increasingly obvious that gambling would start to permeate the fabric of games. In this way, the "gambling turn" is not just about economics but is an expression of the changing beliefs we hold about gambling, whereby we are encouraged to see gambling as recreation. These beliefs are not clear cut and remain deeply contested and thus game designers who implement gambling-like features within their games become embroiled in larger debates about the role and status of gambling in our society. The gambling permeation is a result of all these processes and is an extension of the myriad ways that gambling has become increasingly embedded into everyday life.

\section{REFERENCES}

Albarrán-Torres, C. (2018). Digital gambling: Theorizing gamble-play media. Routledge.

Binde, P. (2005). Gambling across cultures: Mapping worldwide occurrence and learning from Ethnographic Comparison. International Gambling Studies, $5(1), 1-27$.

Boxing Scene. (date unknown). Poker on TV. Available at https://www.boxing scene.com/casino-gambling/21506.php. Accessed 23 September 2020.

Chinn, C. (2004). Better betting with a decent feller: A social history of bookmaking. Aurum.

Clapson, M. (1992). A bit of a flutter. Popular gambling in English society c.18201961. Manchester University Press.

Conolly, A., Davies, B, Fuller, L., Heinze, N., \& Wardle, H. (2018). Gambling behaviour in Great Britain in 2016. Birmingham: Gambling Commission.

Daily Mail. (2001). Betting tax abolished. Available at: https://www.dailymail.co. uk/sport/article-28835/Betting-tax-abolished.html. Accessed 23 July 2020. 
Donovan, T. (2018). It's all a game: A short history of board games. Atlantic.

Edwards, P. (2020). Why the game of life used to have poverty, suicide, and ruin. Vox. Available at https://www.vox.com/2015/1/28/7924487/gameof-life-history. Accessed 10 July 2020.

Eyal, N. (2014). Hooked: How to build habit-forming products. Penguin.

Fury, D. (2000). The real me. Unpublished script for Buffy the Vampire Slayer.

Foulkes, N. (2010). Gentlemen and blackguards: Gambling mania and the plot to steal the Derby of 1844 . Orion.

Grace's Guide to British Industrial History. (2016). Peacock and co. Available at: https://www.gracesguide.co.uk/Peacock_and_Co. Accessed 13 March 2020.

GVC. (2020). 2019 full year results. Available at https://gvc-plc.com/newsre lease/2019-full-year-results /. Accessed 8 October 2020.

Hansard. (1978). House of lords debate 13 December 1978 vol. 397 cc560-602. Available at http://hansard.millbanksystems.com/lords/1978/dec/13/gam bling-need-for-a-national-council. Accessed 17 June 2020.

Hansard. (1980). Information technology 11 July 1980. Available at https://han sard.parliament.uk/Commons/1980-07-11/debates/21d78ebd-bl1c-4a7c8761-46592dc01100/InformationTechnology?highlight=\%22we $\% 20 \mathrm{can} \% 20 \mathrm{f}$ oresee $\% 20$ the $\% 20$ time $\% 20$ when $\% 20$ football $\% 20$ pools $\% 20$ will $\% 20$ be $\% 20$ done $\%$ 20on\%20an\%20automatic\%20basis\%22\#contribution-e7affe0a-bef0-4df39d86-52091859c666. Accessed 23 September 2020.

Hansard. (1991). National lottery debate $14^{\text {th }}$ March 1991. Available at https:// hansard.parliament.uk/Commons/1991-03-14/debates/9c51306f-6d82408a-866d-4c5de2a600c9/NationalLottery?highlight=computer\%20gamb ling\#contribution-139fddd6-4263-4c70-aa96-6b7d51d9a0e3. Accessed 10 June 2020.

Holden, A. (2008). Bigger deal: A year inside the poker boom. Little, Brown and Company.

Hunt, T. (2018). Foreword. In M. Foulston \& K. Volsing (Eds.), Videogames: Design/play/disrupt. V\&A.

Kaser, R. (2020). A history of sex in video games: When has it crossed a line? The Next Web. Available at https://thenextweb.com/gaming/2020/05/22/sexvideo-games-crossed-the-line/. Accessed 15 September 2020.

Kemsley, W. F. F., \& Ginsburg, D. (1951). Consumer expenditure series: Betting in Britain. London: Central Statistics Office.

Kerr, A. (2006) The business and culture of digital games: Gamework/gameplay. Sage.

Laybourn, K. (2008). 'There ought not to be One Law for the Rich and Another for the Poor which is the Case To-day': The Labour Party, lotteries, gaming, gambling and bingo, c.1900-1960s. History, 93(310), 201-223.

Light, R. (2007). The Gambling Act 2005: Regulatory containment and market control. Modern Law Review, 70(4), 626-653. 
Liman, E. (2017). Georgian and Victorian Board Games: The Liman collection. Pointed Leaf Press.

Jensen, J. (2009). Teaching success through play: American board and table games: 1840-1900. The Log Cabin Blogspot. Available at http://logcabinvillage.blo gspot.com/2009/09/game-of-life.html. Accessed 25 July 2020.

Johnson, M., \& Brock, T. (2019). The 'gambling turn' in digital game monetization. Journal of Gaming and Virtual Worlds, 12(2), 145-163.

Juul, J. (2010). A casual revolution: Reinventing video games and their players. MIT Press.

Popovici, A. (2018). The game of clue was borne out of boredom during WWII air raid blackouts. History. Available at https://www.history.com/news/cluegame-origin-wwii. Accessed on 13 July 2020.

Reith, G., (2000). The age of chance: Gambling in western culture. Routledge.

Rowntree, S. (Eds). (1905). Betting and gambling: A national evil. Macmillan.

Seville, A. (2016). The cultural legacy of the royal game of goose: 400 years of printed board games. Grolier Club.

Stanton, R. (2015). A brief history of video games: From Atari to Xbox one. Robinson.

Statista. (2020). King annual revenue 2010-2019. Available at: https://www.sta tista.com/statistics/288974/king-annual-revenue/\#: :text=King\%20annual\% 20revenue $\% 202010 \% 2$ D2019\&text=Founded $\% 20 \mathrm{in} \% 20$ Sweden $\% 20 \mathrm{in} \% 202$ 003,million\%20U.S.\%20dollars\%20in\%202010. Accessed 8 October 2020.

Venturebeat. (2019). Apptopia: Helix Jump led all mobile games in Q4 2018 with 25.6 million daily players. Available at: https://venturebeat.com/2019/ 01/17/apptopia-helix-jump-led-all-mobile-games-in-q4-2018-with-25-6-mil lion-daily-players/ Accessed 7 October 2020.

Wardle, H., et al. (2011). British gambling prevalence survey 2010. TSO.

Williams, D., \& Kahn, A. S. (2013). Games, online and off. In W. Dutton (Eds.), The Oxford handbook of internet studies. Oxford University Press.

Zynga. (2020). United States securities and exchange commission: Form K-10. Available at https://investor.zynga.com/static-files/d91122ee-c93f468b-a48e-6d3b3cl44le3. Accessed 1 October 2020. 
Open Access This chapter is licensed under the terms of the Creative Commons Attribution 4.0 International License (http://creativecommons.org/licenses/ by $/ 4.0 /$ ), which permits use, sharing, adaptation, distribution and reproduction in any medium or format, as long as you give appropriate credit to the original author(s) and the source, provide a link to the Creative Commons license and indicate if changes were made.

The images or other third party material in this chapter are included in the chapter's Creative Commons license, unless indicated otherwise in a credit line to the material. If material is not included in the chapter's Creative Commons license and your intended use is not permitted by statutory regulation or exceeds the permitted use, you will need to obtain permission directly from the copyright holder.

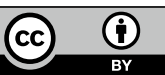

